\title{
Energy and phosphorus recovery from black water
}

\author{
M.S. de Graaff*******, H. Temmink***, G. Zeeman** and C.J.N. Buisman****
}

\begin{abstract}
*Wetsus, centre of excellence for sustainable water technology, P.O. Box 1113, 8900 CC Leeuwarden, the Netherlands; Phone+31 (0)58 2843000 (E-mail: marthe.degraaff@wetsus.nl; hardy.temmink@wetsus.nl) **Wageningen University, Sub-department of Environmental Technology, P.O. Box 8129, 6700 EV Wageningen, the Netherlands; (E-mail: grietje.zeeman@wur.nl; cees.buisman@wur.nl) ***Corresponding author is currently working at KWR Watercycle Research Institute, P.O. Box 1072, 3430 BB Nieuwegein; Phone +31(0)+31(0)306069511
\end{abstract}

\begin{abstract}
Source-separated black water (toilet water) containing $38 \%$ of the organic material and $68 \%$ of the phosphorus in the total household waste(water) stream including kitchen waste, is a potential source for energy and phosphorus recovery. The energy recovered, in the form of electricity and heat, is more than sufficient for anaerobic treatment, nitrogen removal and phosphorus recovery. The phosphorus balance of a UASB reactor treating concentrated black water showed a phosphorus conservation of $61 \%$ in the anaerobic effluent. Precipitation of phosphate as struvite from this stream resulted in a recovery of $0.22 \mathrm{kgP} / \mathrm{p} / \mathrm{y}$, representing $10 \%$ of the artificial phosphorus fertilizer production in the world. The remaining part of the phosphorus ended up in the anaerobic sludge, mainly due to precipitation (39\%). Low dilution and a high $\mathrm{pH}$ favour the accumulation of phosphorus in the anaerobic sludge and this sludge could be used as a phosphorus-enriched organic fertilizer, provided that it is safe regarding heavy metals, pathogens and micro-pollutants.
\end{abstract}

Keywords

anaerobic treatment, black water, biogas production, phosphorus recovery, separation at source, struvite

\section{INTRODUCTION}

New sanitation concepts are based on separation at source of household wastewater streams into grey water and black water (faeces and urine) or into grey water, urine and brown water (faeces), and have a large potential to recover the important resources energy, nutrients and water. Anaerobic treatment is regarded as the core technology for energy and nutrient recovery from source separated domestic wastewater (Otterpohl et al., 1999; Kujawa-Roeleveld and Zeeman, 2006). Previous research showed that concentrated black water (faeces and urine collected in a vacuum toilet) can be efficiently treated in a UASB (Upflow anaerobic sludge blanket) reactor at a relatively short hydraulic retention time (HRT) of 9.1 days (de Graaff et al., 2010), in a UASB septic tank at a longer HRT of 29 days (Kujawa-Roeleveld et al., 2005) or in a CSTR at an HRT of 20 days (Wendland et al., 2007). A methane production of $1.8 \mathrm{~m}^{3} \mathrm{CH}_{4}$ per $\mathrm{m}^{3}$ of black water can be achieved, which can be converted to $56 \mathrm{MJ} / \mathrm{p} / \mathrm{y}$ as electricity and $84 \mathrm{MJ} / \mathrm{p} / \mathrm{y}$ as heat by combined heat and power (CHP) (de Graaff et al., 2010).

The nutrients are largely conserved in the effluent of the anaerobic treatment step. Van Voorthuizen et al. (2008) reported a phosphorus removal of only 5\% during anaerobic treatment of black water collected with conventional flush toilets (6L per flush), i.e. $95 \%$ was conserved in the effluent. However, for more concentrated black water, collected with vacuum toilets (1L per flush), 40\% of the phosphorus was removed when applying UASB-septic tank (Kujawa-Roeleveld et al., 2005).

Worldwide, 3 million tons $\mathrm{P} /$ year are excreted by humans, which represents $21 \%$ of the total amount of artificial phosphorus fertilizer production (14.9 million tons P/year) (Cordell et al., 2009). Because domestic wastewater contains low amounts of heavy metals compared to industrial wastewater, relatively clean phosphorus rich products can be produced from black water, that could be reused in agriculture as a fertilizer (Winker et al., 2009) or as a raw material for the phosphorus 
industry (Schipper et al., 2007).

Phosphorus is produced from mined phosphate rock, mainly for the production of fertilizers $(85 \%$, 14.9 million ton P/year) (Cordell et al., 2009). However, phosphorus rock is a limiting, nonrenewable resource, and it is estimated that the global phosphate rock reserves will be depleted in 50-100 years (Cordell et al., 2009). Although there are disagreements on the total global phosphate rock reserves, for many countries these are already becoming a strategic resource (Gilbert, 2009). Mining of phosphate rock also has a large negative environmental impact because it results in the production of gypsum that is contaminated with heavy metals and radioactive elements (Wilsenach and Van Loosdrecht, 2003). A large fraction of mined phosphate rock finally ends up in the oceans, causing anoxic events and a negative effect on marine life. Clearly, to prevent a global phosphorus crisis, the focus should be much more on recycling of phosphorus (Gilbert, 2009).

This paper will show the possibilities to recover phosphorus from concentrated black water. Furthermore the recovery of resources from black water is discussed with respect to energy production and energy requirements for the treatment of black water.

\section{MATERIALS AND METHODS}

\section{Anaerobic black water treatment in a UASB reactor}

Black water (BW), collected in vacuum toilets, was obtained from the DeSaR (Decentralized Sanitation and Reuse) demonstration site in Sneek (Friesland, NL). Every two weeks jerry cans were filled with black water from the buffer tank at the demonstration site (HRT of $4 \mathrm{~h}$, not cooled), transported to the lab and stored at $4{ }^{\circ} \mathrm{C}$. The black water was used as the influent for anaerobic treatment in a UASB reactor (50L) (de Graaff et al., 2010).

\section{Phosphorus mass balance of the UASB reactor}

The phosphorus mass balance of the UASB reactor was established over the first 951 days of operation (equation 1).

$\mathrm{P}_{\text {influent }}=\mathrm{P}_{\text {effluent }}+\mathrm{P}_{\text {sludge, wasted }}+\mathrm{P}_{\text {sludge,reactor }}$

Influent (black water) and effluent samples (125 samples, taken once a week) were analyzed for total phosphorus (TP). $\mathrm{P}_{\text {influent }}$ and $\mathrm{P}_{\text {effluent }}$ were defined as the accumulative phosphorus load in the black water and effluent respectively (all in $\mathrm{gP}$ ).

The amount of phosphorus in sludge was calculated based on the TP concentration of the sludge (16

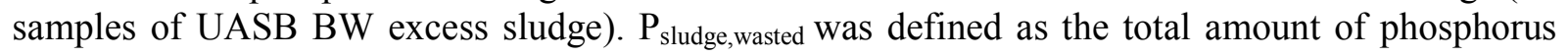
wasted with excess sludge (in $\mathrm{gP}$ ). $\mathrm{P}_{\text {sludge, reactor }}$ was defined as the amount of phosphorus that accumulated in the UASB reactor (in $\mathrm{gP}$ ), based on a sludge bed volume of $75 \%$ of the reactor liquid volume and the TP concentration of the sludge.

\section{Batch tests for struvite precipitation}

Stirred beaker (0.6L) batch tests (magnetic stirrer, $100-250 \mathrm{rpm}$ ) were carried out to investigate phosphate removal by struvite precipitation in the UASB effluent, by adding a magnesium solution $\left(2 \mathrm{M} \mathrm{MgCl}_{2}\right)$. Six duplo tests were carried out, all during the period between day $265-410$ of UASB reactor operation. Varying initial molar ratios of $\mathrm{Mg}: \mathrm{PO}_{4}(1.0: 1,1.3: 1$ and 1.8:1) and two different initial $\mathrm{pH}$ 's were applied (original $\mathrm{pH}$ and $\mathrm{pH}$ of 9.0, adjusted with $4 \mathrm{M} \mathrm{NaOH}$ before addition of magnesium). Samples were taken before addition of magnesium and 15, 30 and 60 minutes after addition of magnesium. Samples were filtered immediately over an ashless black ribbon paper filter (Schleicher \& Schuell) and prepared for analysis of the dissolved phosphate and magnesium concentrations. Temperature, $\mathrm{pH}$, redox and conductivity were measured (WTW $\mathrm{pH} /$ cond $340 \mathrm{i}$ meter) before taking the samples. 


\begin{abstract}
Analyses
TP was determined according to standard methods using commercially available DrLange ${ }^{\circledR}$ test kits (Hach-Lange). Samples were diluted 20 times prior to analysis to exclude possible interference of other ions on the analysis.

The free phosphate $\left(\mathrm{PO}_{4}-\mathrm{P}\right)$ concentration in membrane filtered samples $(0.45 \mu \mathrm{m}$ Cronus filter PTFE) was determined by ion chromatography (Metrohm 761 Compact IC). Total soluble phosphorus $\left(\mathrm{TP}_{\text {soluble }}\right)$ in membrane filtered samples $(0.45 \mu \mathrm{m}$ Cronus filter PTFE) was determined with ICP-OES (Inductively coupled plasma optical emission spectrometry, Perkin Elmer Optima 5300 DV).

Sludge samples were destructed using the Ethos 1 Advanced Microwave digestion system of Milestone. Two grams of sample were put into a special microwave vessel, $10 \mathrm{~mL}$ of $\mathrm{HNO}_{3}(68 \%)$ was added and milliQ water was added up to a total volume of $30 \mathrm{~mL}$. The vessels were placed into the microwave. Samples were heated to $180{ }^{\circ} \mathrm{C}$ in 15 minutes and this temperature was maintained for another 15 minutes. After cooling down, the contents of the vessels were transferred to a 100 $\mathrm{mL}$ flask and diluted to $1 \%$ acid for analysis of $\mathrm{P}$ by ICP-OES.

Total Suspended Solids (TSS) and Volatile Suspended Solids (VSS) were determined according to standard methods using the ashless black ribbon paper filter (Schleicher \& Schuell).

\section{Simulation of chemical precipitation in black water}

To gain more insight in chemical precipitation that might occur in the black water and in the UASB reactor, these processes were simulated in the OLI Stream Analyzer (version 2.0, OLI Systems). A theoretical composition of black water was calculated using literature data on the composition of faeces and urine (Kujawa-Roeleveld and Zeeman, 2006; Maurer et al., 2006) and using the composition of drinking water in Friesland (www.vitens.nl). A $\mathrm{pH}$ survey by adding $\mathrm{NaOH}$ and $\mathrm{HCl}$ was carried out from $\mathrm{pH} 5$ to 10 to determine the effect of $\mathrm{pH}$ on the composition of the black water. Because struvite is not present in the main database of OLI Stream analyzer, a separate database was used, provided by OLI Systems Inc. Details about chemical models, databases and about OLI Stream analyzer can be found on the website of OLI Systems.
\end{abstract}

\title{
RESULTS AND DISCUSSION
}

\section{P balance UASB}

Figure 1 shows the phosphorus mass balance over the UASB reactor. Only $61 \%$ of the TP left the UASB reactor with the effluent, $18 \%$ was wasted with the sludge and $8 \%$ accumulated in the reactor. About $13 \%$ of the TP was missing, which could be due to errors introduced by sampling and analysis. Furthermore some precipitates were observed on the walls and bottom of the UASB reactor, which were not wasted with excess sludge and could therefore partly explain the missing TP. The mean phosphorus content in the UASB sludge was $51 \mathrm{mgP} / \mathrm{gTSS}\left(\mathrm{sd}^{1}=12\right)$, which is much higher than the typical content of bacteria cells of $2.0 \%(20 \mathrm{mgP} / \mathrm{g}$ dry weight, (Tchobanoglous et al., 2003)).

\section{Concentrations in BW and effluent}

Table 1 gives the measured concentrations of influent black water. The results of table 1 show that $60 \%$ of the phosphorus in black water was present as precipitates or was associated with suspended solids. Because the faeces exist for a large part of bacteria (Vinnerås, 2002), it was estimated that 67 $\mathrm{mgP} / \mathrm{L}$ in first period and $54 \mathrm{mgP} / \mathrm{L}$ in the second period was organically bound in suspended solids

${ }^{1} \mathrm{sd}=$ standard deviation 
(using a typical phosphorus content of bacterial cells of $2.0 \%$ (Tchobanoglous et al., 2003)). This corresponds with $52-59 \%$ of the TP associated with solids. The remaining phosphorus in the suspended solids could be mineral calcium phosphates originating from faeces (Vinnerås, 2002) and other precipitates from urine such as struvite (Udert et al., 2003), but this was not further quantified.

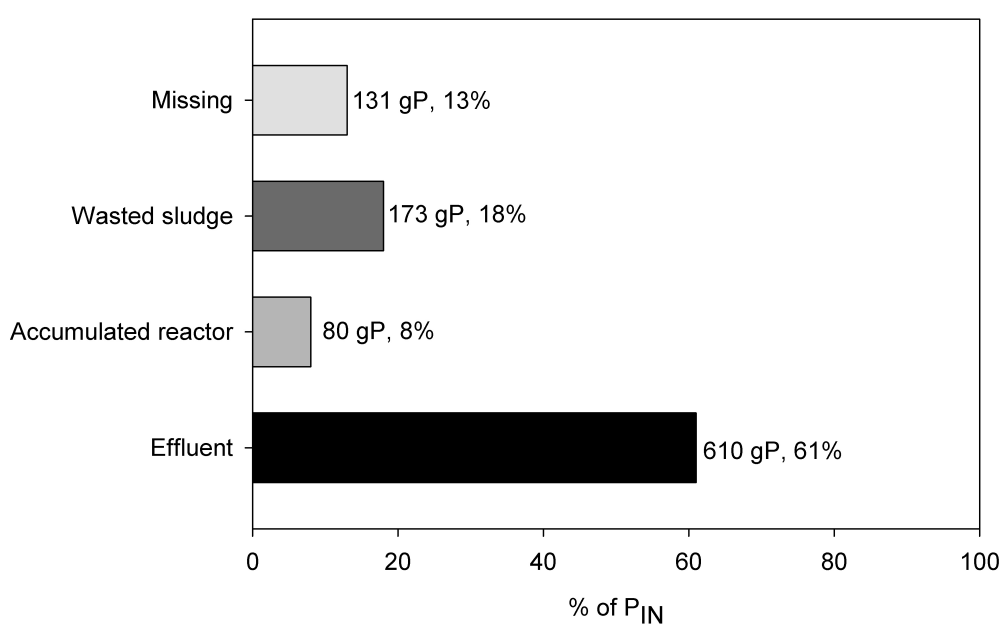

Figure 1. Phosphorus balance of the UASB reactor treating concentrated black water over the first 951 days of operation; numbers are the accumulative load of phosphorus (The total amount of TP fed to the reactor during this period was $994 \mathrm{gP}$ ).

Most of the soluble phosphorus $\left(\mathrm{TP}_{\text {soluble }}\right)$ was present as free phosphate $\left(\mathrm{PO}_{4}-\mathrm{P}\right)$, which was $36 \%$ of $\mathrm{TP}_{\mathrm{IN}}($ table 1). When assuming that all phosphate from urine was excreted in soluble inorganic form (Vinnerås, 2002), a much higher $\mathrm{PO}_{4}-\mathrm{P}$ concentration of $107 \mathrm{mg} / \mathrm{L}$ was estimated. During transport and storage of black water free phosphate from urine may have precipitated, resulting in relatively low $\mathrm{PO}_{4}-\mathrm{P}$ concentrations in the black water, respectively $79 \mathrm{mg} / \mathrm{L}$ and $54 \mathrm{mg} / \mathrm{L}$ in the first and second period. Research on black water with a dilution factor of 21 , showed a $\mathrm{PO}_{4}-\mathrm{P}$ concentration of $27 \mathrm{mg} / \mathrm{L}$ (van Voorthuizen et al., 2008), which corresponds well with the estimated value in of 25 $\mathrm{mgP} / \mathrm{L}$, assuming that all phosphate from urine was excreted in soluble inorganic form (Vinnerås, 2002).

Table 1 Measured characteristics of influent concentrated black water

\begin{tabular}{|c|c|c|c|c|c|c|}
\hline & \multirow[t]{2}{*}{ unit } & \multicolumn{4}{|c|}{$\begin{array}{l}\text { UASB Influent (concentrated black water) } \\
\text { (125 samples) }\end{array}$} & \multirow[t]{2}{*}{$\begin{array}{l}\% \text { of } \\
\mathrm{TP}_{\mathrm{IN}}\end{array}$} \\
\hline & & $\begin{array}{c}1^{\text {st }} \text { period } \\
\text { (day } 1-518)\end{array}$ & $\mathrm{sd}$ & $\begin{array}{c}2^{\text {nd }} \text { period } \\
\text { (day } 519- \\
951 \text { ) }\end{array}$ & $\mathrm{sd}$ & \\
\hline $\mathrm{pH}$ & - & 8.8 & 0.22 & 8.6 & 0.53 & \\
\hline TP & $\mathrm{mg} / \mathrm{L}$ & 220 & 67 & 148 & 64 & \\
\hline $\mathrm{TP}_{\mathrm{SS}}=\mathrm{TP}-\mathrm{TP}_{\text {soluble }}$ & $\mathrm{mg} / \mathrm{L}$ & 130 & - & 91 & - & $60 \%$ \\
\hline $\mathrm{TP}_{\text {soluble }}$ & $\mathrm{mg} / \mathrm{L}$ & 90 & 8.7 & 57 & 18 & $40 \%$ \\
\hline $\mathrm{PO}_{4}-\mathrm{P}$ & $\mathrm{mg} / \mathrm{L}$ & 79 & 8.5 & 54 & 27 & $36 \%$ \\
\hline VSS & $\mathrm{g} / \mathrm{L}$ & 3.3 & 1.4 & 2.7 & 1.4 & \\
\hline
\end{tabular}

sd = standard deviation

During anaerobic treatment the free phosphate concentration increased from $79 \mathrm{mgPO}_{4}-\mathrm{P} / \mathrm{L}$ to 92 $\mathrm{mgPO}_{4}-\mathrm{P} / \mathrm{L}$ in the first period and from 54 to $69 \mathrm{mgPO}_{4}-\mathrm{P} / \mathrm{L}$ in the second period (tables 1 and 2 ). This probably was caused by hydrolysis of suspended solids containing organically bound phosphorus and by a decrease in $\mathrm{pH}$ during anaerobic treatment (from $8.6-8.8$ in black water to 
$7.4-7.6$ in UASB effluent, tables 1 and 2) solubilising inorganic phosphates. The effluent contained $61 \%$ of the TP in the influent black water, of which the main part was present as free phosphate (44\% of the influent load of TP). A small fraction of the phosphorus left the UASB reactor associated with solids in the effluent, on average $14 \%$ (table 2 ).

Table 2 Measured characteristics of the UASB effluent

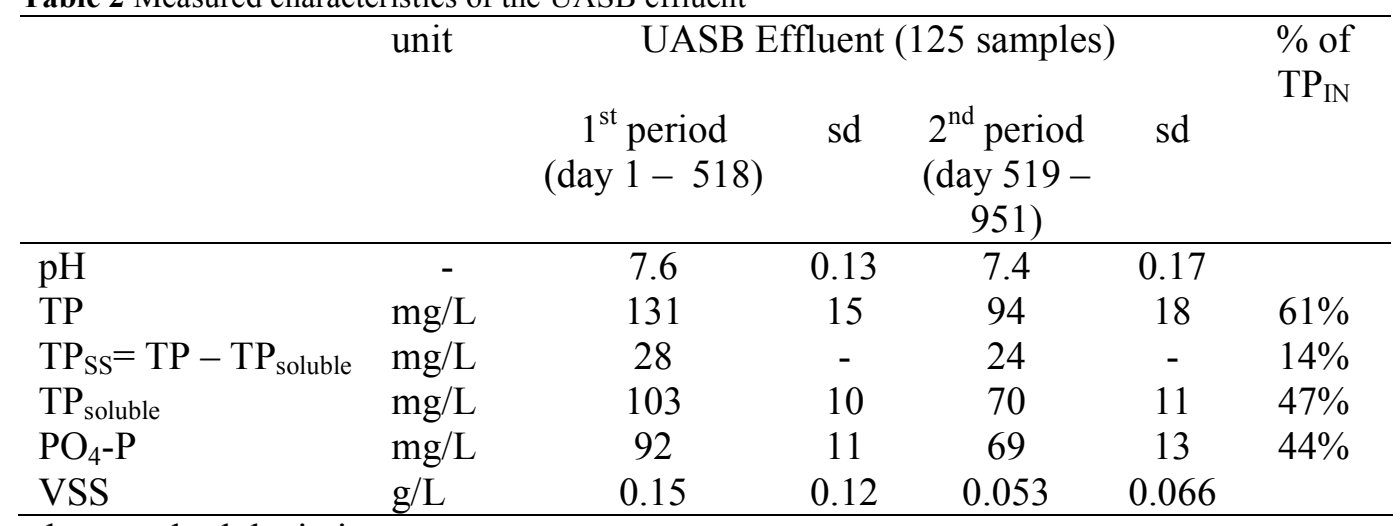

sd $=$ standard deviation

\section{Simulation of chemical precipitation in black water}

Low dilution and high $\mathrm{pH}$ seem to play an important role regarding the availability of free phosphate in the black water and during anaerobic treatment for subsequent phosphorus recovery by struvite precipitation. Both aspects were further investigated by simulating this chemical precipitation in the black water.

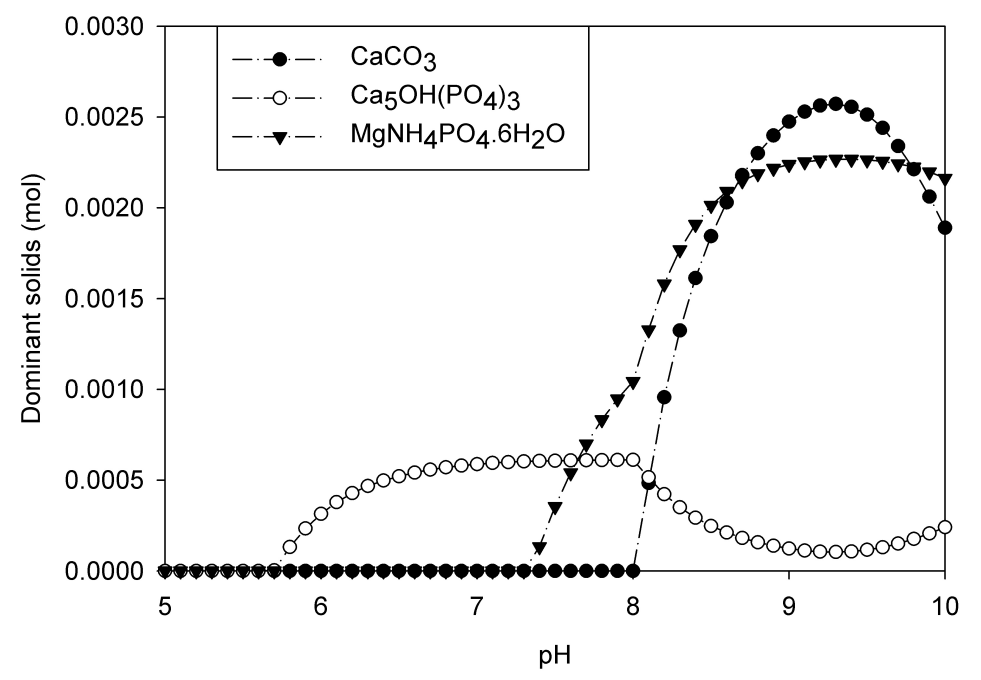

Figure 2 The predicted effect of $\mathrm{pH}$ in concentrated black water on the precipitation of calcite $\left(\mathrm{CaCO}_{3}\right)$, hydroxyapatite $\left(\mathrm{Ca}_{5} \mathrm{OH}\left(\mathrm{PO}_{4}\right)_{3}\right)$ and struvite $\left(\mathrm{MgNH}_{4} \mathrm{PO}_{4} \cdot 6 \mathrm{H}_{2} \mathrm{O}\right)$.

The results in figure 2 clearly show that struvite is likely to precipitate when the $\mathrm{pH}$ in black water is higher than 7.4. Because the $\mathrm{pH}$ of the black water used in this research attained values of $8.6-$ 8.8 (table 1), struvite and hydroxyapatite will likely precipitate during storage and transport. It should be mentioned that kinetics are not taken into account in the simulation, which will have an effect on the type of precipitates formed (Musvoto et al., 2000). Therefore, the results from the simulation are indicative, showing the possible effect of the amount of flushing water and $\mathrm{pH}$. This was also shown for the separate collection of urine, where the risk of blockages can be diminished by urine dilution (Udert et al., 2003). Similar effect of $\mathrm{pH}$ can be expected for the phosphorus 
distribution in the UASB reactor.

The composition of tap water will also have a large effect on the concentrations in black water, because the tap water that was used in this research was relatively soft compared to tap waters in other regions or countries (e.g. tap water in Germany contains up to $199 \mathrm{mg} / \mathrm{L}$ of calcium). The use of hard tap water will result in more precipitation of calcium phosphates in concentrated black water, reducing the availability of $\mathrm{PO}_{4}-\mathrm{P}$ in the anaerobic effluent.

\section{Struvite precipitation}

Batch precipitation tests were carried out at different $\mathrm{pH}$ values (8 or 9) and at different initial molar ratios of magnesium to phosphate. The results in table 3 show that the removal efficiencies of phosphate depended on the applied $\mathrm{pH}$ as well as the surplus of magnesium that was added. Either by adding a surplus of magnesium (e.g. $\mathrm{Mg}: \mathrm{PO}_{4} 1.5: 1$ at $\mathrm{pH} 8.0$ ) or by adjusting the $\mathrm{pH}$ to 9.0 at a lower $\mathrm{Mg}: \mathrm{PO}_{4}$ ratio of 1.3:1, a removal efficiency of $90 \%$ could be achieved, which was similar as in other research reviewed by Le Corre (2009) (60-98\%). A higher $\mathrm{Mg}: \mathrm{PO}_{4}$ ratio of 1.8:1 did not significantly contribute to an improved removal efficiency (table 3). Using these results, $0.15 \mathrm{~kg}$ $\mathrm{PO}_{4}-\mathrm{P} / \mathrm{p} / \mathrm{y}$ can be recovered in the form of struvite (based on a $\mathrm{PO}_{4}-\mathrm{P}$ concentration of $92 \mathrm{mg} / \mathrm{L}$ and a black water production of $5 \mathrm{~L} / \mathrm{p} / \mathrm{d}$ ). Because together with the struvite, suspended solids will be removed as well, a maximum of $0.22 \mathrm{kgP} / \mathrm{p} / \mathrm{y}$ can be recovered from UASB effluent (based on 131 $\mathrm{mg} \mathrm{TP} / \mathrm{L}$ ). Obviously, latter will reduce the purity of the produced struvite. The recovered struvite would represent $10 \%$ of the artificial phosphorus fertilizer production worldwide (14.9 million tP/year, (Cordell et al., 2009)).

Table 3 Phosphate removal efficiencies in UASB effluent by the addition of different amounts of magnesium and at different $\mathrm{pH}$ after 60 minutes

\begin{tabular}{ccc}
\hline molar ratio $\mathrm{Mg}: \mathrm{PO}_{4}$ & $\mathrm{pH} 8.0(\mathrm{sd})$ & $\mathrm{pH} 9.0(\mathrm{sd})$ \\
\hline $1.0: 1$ & $72 \%(3.5 \%)$ & $82 \%(8.2 \%)$ \\
$1.3: 1$ & - & $91 \%(0.7 \%)$ \\
$1.5: 1$ & $90 \%(0.0 \%)$ & $96 \%(0.7 \%)$ \\
$1.8: 1$ & - & $92 \%(0.7 \%)$ \\
\hline
\end{tabular}

Precipitation of struvite from urine showed that the struvite can be recovered free from organic micro-pollutants and free from most of the heavy metals present in urine (Ronteltap et al., 2007). More research with respect to micro-pollutants in struvite recovered from UASB effluent is needed, because the co-precipitated solids and organic material may contain adsorbed micro-pollutants.

The main challenges to make struvite precipitation for phosphate recovery a successful technology, are the quality of the struvite and the economic value of the struvite (Le Corre et al., 2009). In Japan struvite produced from digester liquor was successfully sold to fertiliser companies (Ueno and Fujii, 2001). Recently the struvite produced from an industrial wastewater treatment plant treating potato wastewater in Steenderen (NL) is being used by a company producing cattle fodder ${ }^{2}$, showing an increasing interest for struvite as a valuable product.

\section{Energy recovery from black water}

The amount of electricity that can be produced is significant in terms of wastewater treatment. Whereas conventional wastewater treatment plants consume $96 \mathrm{MJ} / \mathrm{p} / \mathrm{y}$ or $26.6 \mathrm{kWh} / \mathrm{p} / \mathrm{y}$ (Frijns et al., 2008), from the produced methane in the black water treatment concept $56 \mathrm{MJ} / \mathrm{p} / \mathrm{y}$ can be recovered as electricity and $84 \mathrm{MJ} / \mathrm{p} / \mathrm{y}$ as heat. An estimation of the energy production and consumption in the black water treatment concept is presented in table 4 , and is compared with

\footnotetext{
2 http://www.netserver2.net/waterforum/index.asp?url=/template_a1.asp\&que=paginanr=4894, news item in Dutch, $31^{\text {st }}$ March 2009
} 
conventional wastewater treatment. In the estimation nitrogen removal from black water is included, which can be achieved with the energy efficient process of partial nitritation-anammox (Vlaeminck et al., 2009; de Graaff et al., submitted).

Table 4 shows that $22.5 \mathrm{MJ} / \mathrm{p} / \mathrm{y}$ of electricity is gained in the black water treatment concept, whereas in sewerage and conventional WWTPs $107 \mathrm{MJ} / \mathrm{p} / \mathrm{y}$ is lost. These numbers provide an indication, because energy needed for the production of hardware such as reactors and pumps etc. and heat losses are excluded. Table 4 shows that the electricity that is produced from black water can more than compensate for the electricity demand of nitrogen removal and phosphorus recovery. Furthermore, by using less drinking water for toilet flushing, $25 \%$ of the total drinking water consumption in a household can be saved, which results in a further saving of about $19 \mathrm{MJ} / \mathrm{p} / \mathrm{y}$ (table 4). More savings could be achieved by reusing the struvite as a $\mathrm{P}$ fertilizer, requiring less fossil fuels for synthetic fertilizer production. This was however not further quantified.

Table 4 Energy production and consumption in the black water treatment concept and conventional WWTPs.

\begin{tabular}{|c|c|c|c|c|}
\hline $\begin{array}{l}\text { Black water } \\
(5 \mathrm{~L} / \mathrm{p} / \mathrm{d})\end{array}$ & $\begin{array}{l}\mathrm{MJ} / \mathrm{p} / \mathrm{y} \\
\text { electricity }\end{array}$ & $\begin{array}{c}\mathrm{MJ} / \mathrm{p} / \mathrm{y} \\
\text { heat }\end{array}$ & $\begin{array}{l}\text { Conventional WWTP, } \\
\text { domestic sewage } \\
(124 \mathrm{~L} / \mathrm{p} / \mathrm{d})\end{array}$ & $\mathrm{MJ} / \mathrm{p} / \mathrm{y}$ \\
\hline Vacuum transport $^{a}$ & -14 & & Sewerage $^{f}$ & -43 \\
\hline BW heating ${ }^{b}$ & & -80 & $\mathrm{WWTP}^{\mathrm{f}}$ & -96 \\
\hline Biogas production ${ }^{c}$ & +56 & +84 & $\begin{array}{l}\text { Biogas production from } \\
\text { sludge digestion }{ }^{f}\end{array}$ & +32 \\
\hline $\begin{array}{l}\text { P removal by struvite } \\
\text { precipitation }\end{array}$ & -3.5 & & & \\
\hline $\begin{array}{l}\text { N removal by nitritation- } \\
\text { anammox } \\
\text { d }\end{array}$ & -16 & & & \\
\hline Total & +22.5 & & & -107 \\
\hline $\begin{array}{l}\text { Savings: } \\
\text { Drinking water production }\end{array}$ & +19 & & & \\
\hline
\end{tabular}

${ }^{\mathrm{a}} 4 \mathrm{kWh} / \mathrm{p} / \mathrm{y}$, most energy efficient vacuum toilet (WRS, 2001); ${ }^{b}$ increase of 9 degrees (worst case), transfer efficiency of $85 \%$; ${ }^{\mathrm{c}} 12.5 \mathrm{~L} \mathrm{CH}_{4} / \mathrm{p} / \mathrm{d}, 35.6 \mathrm{MJ} / \mathrm{m}^{3} \mathrm{CH}_{4}, 85 \%$ efficiency $(40 \%$ electricity and $60 \%$ heat); ${ }^{\mathrm{d}}$ (Maurer et al., 2003); ${ }^{\mathrm{e}} 0.47 \mathrm{kWh} / \mathrm{m}^{3}$ (Vewin, 2006); ${ }^{\mathrm{f}}$ Including $\mathrm{N}$ and $\mathrm{P}$ removal, (Frijns et al., 2008)

\section{CONCLUSIONS}

New sanitation concepts, based on separation at source of household wastewater streams have a large potential to recover the important resources energy, nutrients and water. Anaerobic treatment of black water, as the core technology for energy and nutrient recovery, provides sufficient energy for the combined anaerobic treatment, nitrogen removal and phosphorus recovery. In the anaerobic effluent of a UASB reactor treating concentrated black water, $61 \%$ of the phosphorus was conserved. Phosphate can easily be removed from anaerobic effluent by struvite precipitation, recovering $0.22 \mathrm{kgP} / \mathrm{p} / \mathrm{y}$, which represents $10 \%$ of the artificial phosphorus fertilizer production in the world. The remaining phosphorus ended up in the anaerobic sludge due to the low dilution factor. This sludge might be used as a phosphorus-enriched organic fertilizer, provided that it is safe regarding heavy metals, pathogens and micro-pollutants. 


\section{References}

Cordell, D., Drangert, J.-O., and White, S. (2009). The story of phosphorus: Global food security and food for thought. Global Environmental Change, 19, 292-305.

de Graaff, M. S., Zeeman, G., Temmink, H., and Buisman, C. J. N. (2010). Anaerobic treatment of concentrated black water in a UASB reactor at a short HRT. Water, 2, doi:10.3390/w20x000x.

de Graaff, M. S., Temmink, H., Zeeman, G., van Loosdrecht, M. C. M., and Buisman, C. J. N. (submitted). Autotrophic nitrogen removal from black water: calcium addition as a requirement for settleability. Water Research.

Frijns, J., Mulder, M., and Roorda, J. (2008). In Dutch: Op weg naar een klimaatneutrale waterketen. STOWA 2008-17.

Gilbert, N. (2009). The disappearing nutrient, News Feature. Nature, 461, 716-718.

Kujawa-Roeleveld, K., Fernandes, T., Wiryawan, Y., Tawfik, A., Visser, M., and Zeeman, G. (2005). Performance of UASB septic tank for treatment of concentrated black water within DESAR concept. Water Science and Technology, 52 (1-2), 307-313.

Kujawa-Roeleveld, K., and Zeeman, G. (2006). Anaerobic treatment in decentralised and source-separation-based sanitation concepts. Reviews in Environmental Science and Bio/Technology, 5, 115-139.

Le Corre, K. S., Valsami-Jones, E., Hobbs, P., and Parsons, S. A. (2009). Phosphorus Recovery from Wastewater by Struvite Crystallization: A Review. Critical Reviews in Environmental Science and Technology, 39, 433-477.

Maurer, M., Schwegler, P., and Larsen, T. A. (2003). Nutrients in urine: energetic aspects of removal and recovery. Water Science and Technology, 48 (1), 37-46.

Maurer, M., Pronk, W., and Larsen, T. A. (2006). Treatment processes for source-separated urine. Water Research, 40, $3151-3166$.

Musvoto, E. V., Wentzel, M. C., and Ekama, G. A. (2000). Integrated chemical-physical processes modelling - II. Simulating aeration treatment of anaerobic digester supernatants. Water Research, 34 (6), 1868-1880.

Otterpohl, R., Albold, A., and Oldenburg, M. (1999). Source control in urban sanitation and waste management: ten systems with reuse of resources. Water Science and Technology, 39 (5), 153-160.

Ronteltap, M., Maurer, M., and Gujer, W. (2007). The behaviour of pharmaceuticals and heavy metals during struvite precipitation in urine. Water Research, 41, 1859-1868.

Schipper, W. J., Klapwijk, A., Potjer, B., Rulkens, W. H., Temmink, B. G., Kiestra, F. D. G., and Lijmbach, A. C. M. (2007). Phosphate recycling in the phosphorus industry - with updated information up to january 2007 availabe from http://www.thermphos.com/Documentation/ /media/Pdf/documents/PhosphorusRecycling\%20pdf.ashx. Environmental Technology, 2001, 22 (11), 1337-1345.

Tchobanoglous, G., Burton, F. L., and Stensel, H. D. (2003). "Wastewater Engineering - Treatment and Reuse." fourth ed. McGrawHill series in civil and environmental engineering (M. E. Inc., Ed.) McGraw-Hill, New York.

Udert, K. M., Larsen, T. A., and Gujer, W. (2003). Estimating the precipitation potential in urine-collecting systems. Water Research, $37(11), 2667-2677$.

Ueno, Y., and Fujii, M. (2001). Three years experience of operating and selling recovered struvite from full-scale plant. Environmental Technology, 22 (11), 1373-1381.

van Voorthuizen, E., Zwijnenburg, A., van der Meer, W., and Temmink, H. (2008). Biological black water treatment combined with membrane separation. Water Research, 42 (16), 4334-4340.

Vewin (2006). Reflections on performance. Vewin no. 2007/80/6292, available from http://www.vewin.nl/SiteCollectionDocuments/Publicaties/Overige\%20Vewinuitgaven/2007/Reflections\%20on\%20performance\%202006.pdf. Den Haag, the Netherlands.

Vinnerås, B. (2002). Possibilities for sustainable nutrient recycling by faecal separation combined with urine diversion, Department of Agricultureal Engineering. Swedish University of Agricultural Sciences.

Vlaeminck, S. E., Terada, A., Smets, B. F., van der Linden, D., Boon, N., Verstraete, W., and Carballa, M. (2009). Nitrogen removal from digested black water by one-stage partial nitritation and anammox. Environmental Science and Technology, 43 (13), 5035-5041.

Wendland, C., Deegener, S., Behrendt, J., Toshev, P., and Otterpohl, R. (2007). Anaerobic digestion of blackwater from vacuum toilets and kitchen refuse in a continuous stirred tank reactor (CSTR). Water Science and Technology, 55 (7), 187-194.

Wilsenach, J. A., and Van Loosdrecht, M. C. M. (2003). Impact of separate urine collection on wastewater treatment systems. Water Science and Technology, 48 (1), 103-110.

Winker, M., Vinnerås, B., Muskolus, A., Arnold, U., and Clemens, J. (2009). Fertiliser products from new sanitation systems: Their potential values and risks. Bioresource Technology, 100, 4090-4096.

WRS (2001). Water Revival Systems Uppsala AB. Market survey - Extremely low flush toilets, plus urine diverting toilets and urinals, for collection of black water and/or urine. SwedEnviro report 2001:1. 